\title{
Çukurova Bölgesinde Farklı Damla Sulama Yöntemleriyle Yetiștirilen Kinoa Bitkisinin Sulama ve Ekonomik Açıdan Değerlendirilmesi
}

\author{
Yeșim BOZKURT ÇOLAK ${ }^{1, *}$ Attila YAZAR² Engin GÖNEN' \\ 'Alata Bahçe Kültürleri Araștırma Enstitüsü Müdürlüğü Toprak ve Su Kaynakları Bölümü \\ ${ }^{2}$ Çukurova Üniversitesi Ziraat Fakültesi Tarımsal Yapılar ve Sulama Bölümü
}

\begin{abstract}
*Sorumlu yazar e-mail (Corresponding author e-mail): yesimcolak@gmail.com
Geliș tarihi (Received) : 17.07.2020

Kabul tarihi (Accepted): 20.10.2020

DOI:10.21657/topraksu.770874
\end{abstract}

\section{Öz}

Bu araștırma Akdeniz iklim koșullarında yüzey ve toprakaltı sulama yöntemlerinde farklı sulama konularının Kinoa verimine etkisi ve ekonomik analizini belirlemek amacıyla 2016 ve 2017 yıllarında Çukurova Üniversitesi Ziraat Fakültesi Tarımsal Yapılar ve Sulama Bölümü Araștırma alanında yürütülmüștür.

Araștırmada iki farklı sulama yöntemi (Yüzey damla (YD), Toprakaltı damla (TD)) ve altı farklı sulama konusu (Tam sulama (FI); geleneksel kısıntılı sulama (DI-75 ve DI-50); kısmi kök kuruluğu (PRD-50); planlanmıș kısıntılı sulama (RDI) ve sulanmayan konu (RF)| olușturulmuștur. Araștırma tesadüf blokları bölünmüș parseller deneme deseninde dört yinelemeli olarak incelenmiștir. Kinoa bitkisinin yüzey damla veya toprakaltı damla sulama yöntemi ile sulanmasının verimde istatistiksel olarak önemli bir fark yaratmadığı, buna karșılık sulama konularına göre verimin 0.01 önem düzeyinde farklı olduğu belirlenmiștir. FI, DI-75, PRD ve RDI konularında benzer ve yüksek verim değerleri elde edilirken, bunları DI-50 ve RF konuları izlemiștir. En yüksek verim her iki deneme yılında FI konusunda (2.906$2468 \mathrm{~kg} \mathrm{ha}^{-1}$ ) alınırken, en düșük verimler ise her iki yılda da RF konusunda (2204-1855 kg ha-1) kaydedilmiștir. Net gelirler sulama konularına göre 2016 yılında 4954-8493 \$ ha-1 arasında, 2017 yılında ise 3270-5906 \$ ha-1 arasında değișmiștir. Ekonomik anlamda ise birim alanda en yüksek net gelir YD sulama yöntemi Fl konusundan elde edilmiștir.

Anahtar Kelimeler: Kinoa, Yüzey Damla, Toprakaltı Damla, Ekonomik Analiz

\section{Irrigation and Economic Evaluation of Quinoa Plant Grown by Different Drip Irrigation Methods in Çukurova Region}

\begin{abstract}
This study was carried out to determine the effect of different irrigation treatmants and economic analysis on surface and subsurface methods in quinoa under the Mediterranean climate conditions at the experimental fields of the Cukurova University during 2016 and 2017 growing seasons in Turkey. In the study, surface drip and subsurface drip methods and four irrigation strategies (Full irrigation, Fl; conventional deficit irrigation, DI-50 and DI-75; and Partial Root-Zone Drying, PRD-50 of full irrigation treatments) also a rain-fed treatment (RF) were considered. The experimental design was split plots with four replications. There was no significant differences in yields between surface and subsurface drip irrigation methods for quinoa however, different irrigation treatments resulted significantly $(\mathrm{P}<0.01)$ for yields. FI, RDI, DI-75, and PRD-50 treatments resulted significantly $(P<0.01)$ greater quinoa grain yields
\end{abstract}


than DI-50 and RF. Maximum yield was obtained from the FI treatment as 2906 and $2468 \mathrm{~kg} \mathrm{ha}^{-1}$; and the lowest yield was obtained from the rainfed treatment (RF) as 2204 and $1855 \mathrm{~kg} \mathrm{ha}^{-1}$, in the experimental years, respectively. Net profit ranged between 4954 to $8493 \$ \mathrm{ha}^{-1}$ in 2016 and 3270 to $5906 \$ \mathrm{ha}^{-1}$ in 2017 according to the irrigation treatments. Full irrigation treatment (FI) under surface drip irrigation method generated the highest net profit.

Keywords: Quinoa, Surface Drip, Subsurface Drip, Net Return

\section{Giriș}

Ülke nüfusunun sürekli ve hızlı artıș göstermesi; insanların beslenmesi, giyinmesi ve yașamı için gerekli diğer intiyaçların artmasına yol açmaktadır. İnsanların intiyaçları bir yandan nüfus büyümesi ile sayısal olarak artmakta, diğer yandan teknolojik gelișmenin yükselttiği yașam standardının getirdiği ilavelerle daha da çoğalmaktadır. Artan nüfusun gıda gereksiniminin karșılanması ve tarımsal sürdürülebilirlik için; a) mevcut su kaynaklarının etkin yönetimi ve su kullanım randımanının artırıması, b) sulama için ek su kaynaklarının geliștirilmesi, c) stres koșullarına toleranslı ve daha az su ile daha fazla verim sağlayabilen yeni ürünlerin geliștirilmesi alınabilecek önlemler arasındadır (Oweis vd., 2003; Yazar vd., 2015). Bu amaçla özellikle çeșitli ekolojik koșullarda kolaylıkla yetișebilecek bitki tür ve çeșitleri ile birim alandan daha fazla besin maddesi üretimi (vitamin, mineral, protein vb.) önem arz etmeye bașlamıștır. Günümüzde iklim ve toprak șartları açısından geniș bir adaptasyon kabiliyetine sahip olması sebebiyle birbirinden farklı coğrafi koșullarda yetișebilen kinoa (Chenopodium quinoa Willd.) bitkisi ilgi odağı olmuștur (Vega-Galvez vd., 2010; Yazar ve İnce Kaya, 2014; Kır ve Temel, 2017).

Ana gen merkezinin Peru ve Bolivya sınırlarındaki And Dağları olan kinoa, bugün dünya üzerinde 50'den fazla ülkede yetiștirilmektedir. Fakat ekim alanlarının ve üretiminin büyük bir kısmı hala Güney Amerika ülkelerindedir. FAO'nun 2017 yılı verilerine göre en fazla üretim yapan ülkeler sırasıyla Bolivya, Peru ve Ekvator'dur. Bu 3 ülkenin toplam ekim alanları ve üretimleri sırasıyla 185350 ha ve 148-720 ton'dur. Üretilen ürünün büyük çoğunluğu ABD ile Avrupa Birliği ülkelerine satılmaktadır. Bunların dıșında da çok sayıda ülke kinoa yetiștiriciliği yapmaktadır (FAO, 2017).

Sulamanın en önemli amaçlarından birisi de kurak dönemlerde yetiștirilen ürünü korumaktır. Bölgemizde kıșlık olarak yetiștirilen ürünlerde genelde susuzluk belirtisi görülmemekle birlikte, erken verim veya zamanla olușan kuraklıklar su açığından kaynaklanan önemli verim düșmelerine neden olabilmektedir. Böyle durumlarda yeni nesil sulama teknolojilerinin kullanılması yanında sulama zamanı ve verilecek sulama suyu miktarının belirlenmesi ișlemini kapsayan sulama programlamasının kullanılması, sınırlı su kaynaklarının optimum kullanımına olanak tanımaktadır (Yazar vd., 2015). İyi planlanmıș bir kısıntılı sulamanın; tam sulamada intiyaç duyulan suyun yarısı kadar sulama suyu ile 1.2 ve 2.0 t ha-1 arasında bir kinoa verimi sağlayabileceği belirtilmiștir (Geerts vd., 2008).

Kinoa yarı-kurak bölgelerde mevcut yağıș koșulları altında rahatlıkla yetiștirilebilmekte (Jensen vd., 2000; Geerts vd., 2008) ve yașanan küçük kuraklıklar verimde azalmalara neden olmamaktadır (Garcia vd., 2003). Hatta yıllık 200 mm'den daha az yağıș alan kumlu topraklarda dahi yetișebildiği rapor edilmiștir (Aguilar ve Jacobsen, 2003). Ancak yağıșların çok sınırlı olduğu özellikle de kuraklık stresine duyarlı olduğu gelișme dönemlerinde sulama yapılarak ekonomik karlııık sağlanabilmektedir (Martinez vd., 2009).

Tarımsal ürün maliyetleri ile ilgili araștırmaların sonuçları, hükümetlerin fiyat politikalarını saptamalarında bașvurabilecekleri bir araç olmaktadır. Tarımsal ürün maliyetleri ișletmelerde özellikle fiziki üretim girdilerinin kullanım düzeylerinin belirlenmesi, ișgücü planlaması, finansman programlarının yapılması ve ürün bütçelerinin hazırlanmasında yaygın olarak kullanılmaktadır (Candemir vd., 2017).

Bu çalıșmada, Çukurova bölgesinde farklı sulama yöntemleri ve farklı sulama konularının yol açtığı verim farklııklarının parasal değerleri maliyetlerle karșılaștırılarak yaratacağı ek gelir kinoa bitkisi için somut olarak ortaya konulmuștur.

\section{MATERYAL VE YÖNTEM}

Araștırma, 2016 ve 2017 yetiștirme dönemlerinde, Çukurova Üniversitesi Ziraat Fakültesi Tarımsal Yapılar ve Sulama Bölümü Deneme Alanı́nda yürütülmüștür. Deneme 
alanının denizden ortalama yüksekliği 20 m olup $36^{\circ} 59^{\prime} \mathrm{N}, 35^{\circ} 18^{\prime} \mathrm{E}$ enlem ve boylamlarında yer almaktadır. Adana Meteoroloji Bölge Müdürlüğü iklim verilerine göre, yörenin uzun yıllık (19502015) yağıș ortalaması 670.8 mm'dir. Bölgede uzun yıllık sıcaklık ortalaması $19.1^{\circ} \mathrm{C}^{\prime}$ dir. Uzun yıllar ölçümlerinde yıllık buharlașma ise 1536 mm'dir. 2016 yılı bitki büyüme mevsimi boyunca 182 mm yağıș, 2016 yılı için toplam 100.7 mm yağıș gerçekleșmiștir. Genel olarak 2016 ve 2017 kinoa yetiștirme dönemindeki sıcaklıklar ve nem değerleri uzun yıllık ortalama değerlere benzer seyretmiș, ancak 2016 yılı yağıș değerleri Nisan ayında $(2.2 \mathrm{~mm})$ ortalama değerlerin çok altında; 2017 yılında ise ortalama değerin üzerinde 197.2 mm) gerçekleșmiștir. Mayıs ve Haziran aylarında ise ortalamanın üzerinde yağıș olmuștur.

Deneme alanı topraklarının $60 \mathrm{~cm}$ profil boyunca killi bünyeye sahip toprağın katmanlara göre $\mathrm{pH}$ 'sı, 7.61-7.87; tuz içeriği 0.12-0.19 dS m-1; hacim ağırlığı 1. 14-1 .30 gcm-3; hacim esasına göre tarla kapasitesi su içeriği \%37-41, solma noktası ise \%24-26 arasında değișmektedir. Toprak profilinin 60 cm'lik derinliğindeki toplam kullanılabilir su miktarı 110 mm'dir.

Araștırma tesadüf blokları bölünmüș parseller deneme desenine göre dört yinelemeli olarak yürütülmüștür. Araștırmada iki farklı sulama yöntemi (Yüzey damla (YD) ve Toprakaltı damla (TD)) ve altı farklı sulama konusu ele alınmıștır. Sulama Konuları: Tam sulama (FI), 60 cm'lik etkili kök derinliğindeki kullanılabilir suyun \%25'i tüketilince eksik toprak neminin tarla kapasitesine getirildiği konu; Geleneksel kısıntılı sulamalar (DI-50) ve (DI-75), FI konusuna uygulanacak suyun yarısının ve \%75'inin verildiği konular; Kısmi kök kuruluğu (PRD-50), her bir sulamada FI konusuna verilecek suyun yarısının dönüșümlü olarak bir lateralden uygulandığı konu; Bir sulamada bir lateralden, izleyen sulamada diğer lateralden su uygulanmıștır. Planlanmıș kısıntıı sulama (RDI), vejetatif büyüme döneminden çiçeklenme bașlangııına dek \%50 kısıntılı sulama, fizyolojik olgunluğa ulașana kadar ise tam sulama uygulanan konu olarak sulamalar yapılmıștır. Sulama yapılmaya konu (RF) yetișme dönemi boyunca sulanmayan, yalnızca çimlenmenin sağlanması amacıyla su uygulanan tanık konu olarak alınmıștır.

Araștırmada, Çukurova bölge koșullarına çok iyi uyum sağlamıș olan Kinoa (cv. Titicaca) çeșidi kullanıımıștır. Deneme alanı toprağı ekimden birkaç gün önce goble-disk ve tapan çekilerek düzeltilip ekime hazır duruma getirilmiștir. Kinoa tohumlarının 25 Mart 2016 ve 21 Mart 2017 tarihlerinde deneme parsellerine elle ekimi yapılmıștır. Her parselde $10 \mathrm{~m}$ uzunluğunda 6 bitki sırası, sıra arası $50 \mathrm{~cm}$, sıra üzeri $10-15 \mathrm{~cm}$ olacak șekilde ekim ișlemi yapılmıștır. Ekimle birlikte deneme parsellerine, $75 \mathrm{~kg} \mathrm{ha}^{-1} \mathrm{~N}$ ve $75 \mathrm{~kg} \mathrm{ha}^{-1} \mathrm{P}_{2} \mathrm{O}_{5}$ saf madde esasına göre 20-20-0 kompoze gübre uygulanmıștır. Ekimden hemen sonra parsellere eșit miktarda can suyu uygulaması yapılmıștır. İkinci gübreleme çiçeklenme bașlangıcında gerçekleștirilmiș ve $75 \mathrm{~kg} \mathrm{ha}^{-1} \mathrm{~N}$ saf madde asasına göre \%46 üre uygulanmıștır. Fizyolojik olgunluğa ulaștıktan sonra her bir parselde kenarlardan birer sıra ve bașlardan birer metre boșluk bırakılarak (8 m uzunluğunda orta dört sıra) Kinoa bitkileri ilk yıl 14 Temmuz 2016 ikinci yıl ise 12 Temmuz 2017 tarihinde el ile hasat edilmiștir.

Yüzey damla sisteminde iletim sisteminde PE borulardan olușan ana boru, manifold ve lateral borular kullanılmıs ve bu borular toprak yüzeyine yerleștirilmiștir. Lateraller $16 \mathrm{~mm}$ çapında olup üzerinde $33 \mathrm{~cm}$ aralıklarla içten geçik (inline) damlatıcıları içermiștir (Betaplast, Adana). Damlatıcı debisi 100 kPa ișletme basıncında 2.0 I $h^{-1}{ }^{\prime}$ tir. Toprağın infiltrasyon özellikleri dikkate alınarak damlatıcı aralığı ve debisi belirlenmiștir. Lateraller; her iki bitki için de her bitki sırasına bir lateral (50 cm aralıklarla), PRD konusunda ise her bitki sırasının sağına ve soluna gelecek șekilde bir lateral $25 \mathrm{~cm}$ aralıklarla (bitki sırasının her iki yanında $25 \mathrm{~cm}$ olacak șekilde) yerleștirilmiștir. TD sulama yönteminde lateraller toprak yüzeyinin 15 cm altına yerleștirilmiștir. Lateraller, çizel ile açılan izlerin temizlenmesiyle olușturulan yüzlek arkların içine yerleștirilmiștir. Bu yöntemde ana hat ve manifold borular deneme alanında toprak yüzeyine yerleștirilmiștir. TD sulama yönteminde 20 mm çapında lateraller, damlatıcı aralığı $40 \mathrm{~cm}$ ve debisi $2.0 \mathrm{~h} \mathrm{~h}^{-1}$ olan içten damlatıcılar kullanılmıștır. Sulama sistem tertibi yüzey damla sulama yöntemine göre yapılırken toprakaltında aynı özelliklerde lateral piyasada bulunamadığında en yakın özellikteki toprakaltı lateral tercih edilmiștir.

Toprak suyu içeriği 0-60 cm'de gravimetrik yöntemle sulamalardan önce alınmıștır. Ayrıca toprak su içeriği günlük olarak 0-40 cm'de toprak su içeriği sensörleri ile izlenmiștir. Toprak su içeriği sensörleri (SM-150, Delta T), parsel ortasına denk gelecek șekilde her sulama konusu için bir tekerrüre 20 ve $40 \mathrm{~cm}$ derinliklere yerleștirilmiștir. 
Üreticilerin, önerilen yeni yetiștirme tekniğini benimsemeleri ancak daha fazla ekonomik getiri elde etmeleri durumunda mümkün olabilmektedir. Deneme sonuçlarının ekonomik değerlendirmesinde genellikle kullanılan Fayda/ MasrafAnalizi ile Kısmi Bütçeleme (Partial Budgeting) yöntemleridir. Bu yöntemde sulama süresi (h), sulamada ișgücü gideri $\left(\$ \mathrm{~h}^{-1}\right)$, toplam sulama ișgücü gideri $(\$)$, su ücreti $\left(\$ h^{-1}\right)$, Kinoa üretim giderleri, birim alanda sulama sistem gideri I\$ ha 1), yıllık sulama sistem gideri, verim $\left(\mathrm{kg} \mathrm{ha}^{-1}\right)$, Kinoa satıș fiyatı (\$ kg-1) verilerinden faydanılarak birim alanda brüt gelir $\left(\$ \mathrm{ha}^{-1} \mathrm{yll}^{-1}\right)$, birim alanda net gelir (\$ ha ${ }^{-1} \mathrm{yll}^{-1}$ ) hesaplamaları yapılmaktadır. Yöntemin sade ve etkili olması nedenleriyle bu araștırmada deneme sonuçlarının ekonomik değerlendirilmesi Kısmi Bütçeleme yönteminden yararlanılmıștır (Barker ve ark., 2003; Kadyampakeni ve ark., 2014). Anılan yöntem, yeni üretim tekniğinin ya da herhangi bir kararın yol açacağı ek faydalarla ek maliyeleri karșılaștırma esasına dayanmaktadır. Sulama dıșındaki tüm yetiștiricilik koșulları sabit tutulacağından ek masraflar yalnızca sulama ile ilgilidir.

Deneme konularına ilișkin derlenen verilerin istatistiksel analizlerinde JUMP paket programı kullanılmıștır. Ortalamaların karșılaștırılmasında LSD yöntemi uygulanmıștır.

\section{BULGULAR VE TARTIȘMA}

Araștırma yıllarında farklı sulama yöntemleri ve konularına ait sulama suyu miktarları ve dane verim değerleri Bozkurt Çolak vd. (2020) tarafından yapılan çalıșmadan alınan veriler Çizelge l'de verilmiștir. Araștırmanın ilk yllında deneme parsellerinde yeknesak bitki gelișimi sağlamak amacıyla konulu sulamaların bașladığı 23.05.2016 tarihine kadar tüm deneme konularına eșit

Çizelge 1. Araștırma yıllarında farklı sulama yöntemleri ve konularına ait sulama suyu miktarları ve dane verim değerleri (Bozkurt Çolak vd., 2020)

Table 1. Irrigation water amounts and grain yield values of different irrigation methods and treatments during the research years

\begin{tabular}{|c|c|c|c|c|}
\hline Yıllar & Sulama Yöntemleri & Sulama Konuları & Sulama Suyu (mm) & Dane Verimi $\left(\mathrm{kg} \mathrm{ha}^{-1}\right)$ \\
\hline \multirow{12}{*}{2016} & \multirow{6}{*}{ YD } & $\mathrm{FI}$ & 149 & 3021 \\
\hline & & Dl-75 & 125 & 2953 \\
\hline & & DI-50 & 99 & 2415 \\
\hline & & PRD-50 & 99 & 2844 \\
\hline & & RDI & 114 & 2801 \\
\hline & & RF & 49 & 2205 \\
\hline & \multirow{6}{*}{ TD } & $\mathrm{FI}$ & 140 & 2891 \\
\hline & & Dl-75 & 118 & 2662 \\
\hline & & DI-50 & 95 & 2548 \\
\hline & & PRD-50 & 95 & 2625 \\
\hline & & RDI & 110 & 2850 \\
\hline & & RF & 49 & 2205 \\
\hline \multirow{12}{*}{2017} & \multirow{6}{*}{ YD } & $\mathrm{FI}$ & 103 & 2454 \\
\hline & & $\mathrm{Dl}-75$ & 77 & 2363 \\
\hline & & Dl-50 & 51 & 2050 \\
\hline & & PRD-50 & 51 & 2276 \\
\hline & & RDI & 103 & 2442 \\
\hline & & RF & 0 & 1856 \\
\hline & \multirow{6}{*}{ TD } & $\mathrm{FI}$ & 92 & 2482 \\
\hline & & $\mathrm{Dl}-75$ & 69 & 2279 \\
\hline & & DI-50 & 46 & 2098 \\
\hline & & PRD-50 & 46 & 2138 \\
\hline & & RDI & 92 & 2435 \\
\hline & & RF & 0 & 1856 \\
\hline
\end{tabular}


miktarda toplam 49 mm su uygulanmıștır. İlk yıl 3 konulu sulama yapılmıștır. YD sulama yönteminde FI konusuna uygulanan toplam sulama suyu miktarı 149 mm olurken Dl-75 konusuna 125 mm, DI-50 ve PRD konularının her birine $99 \mathrm{~mm}$ su uygulanmıștır. RDI uygulamasında çiçeklenme dönemine kadar sulama suyunda \%50 kısıntı yapılmıș, bu tarihten itibaren kök bölgesinde eksik suyun tamamı karșılanmıștır. Böylece RDI konusunda toplam sulama suyu miktarı $114 \mathrm{~mm}$ olmuștur. TD uygulamasında FI konusunda 140 mm, Dl-75 konusunda 118 mm, DI-50 ve PRD konularında ise $95 \mathrm{~mm}$ sulama suyu uygulanmıștır. TD sulama yöntemi RDI konusuna 110 mm sulama suyu verilmiștir.

Araștırmanın ikinci yılında bitkinin ilk gelișim așamasında așırı yağıșlardan dolayı eșit su uygulaması yapılamamıștır. Konulu sulamalara 01 Mayıs 2017 tarihinde bașlanmıș ve 3 konulu sulama uygulaması yapılmıștır. YD sulama yönteminde Fl konusuna uygulanan toplam sulama suyu miktarı 103 mm olurken Dl-75 konusuna 77 mm, DI-50 ve PRD konularının her birine 51 mm su uygulanmıștır. RDI uygulamasında sulamalar çiçeklenme döneminde bașladığından tam sulama kadar su uygulanmıș olup yağıșlar nedeniyle kısıntı uygulanamamıștır. Böylece RDI konusunda toplam sulama suyu miktarı 103 mm olmuștur. TD uygulamasında FI konusunda 92 mm, Dl-75 konusunda $69 \mathrm{~mm}$, DI-50 ve PRD konularında ise 46 mm sulama suyu uygulanmıștır. RDI sulama konusuna $92 \mathrm{~mm}$ sulama suyu uygulanmıștır. Araștırmanın ikinci yılında konulara uygulanan toplam sulama suyu miktarları ilk yıla kıyasla daha az olmuștur. Bunun nedeni ikinci yılda büyüme döneminde kaydedilen yağıșların daha fazla olmasıdır. Sezen vd. (2018), Çukurova bölgesinde kinoa (Titicaca) bitkisinde farklı büyüme dönemlerinde uygulanan drenaj suyunun verim, verim bileșenleri, su kullanım etkinliği ve tuz birikimi üzerine etkisini inceledikleri çalıșmada çizgi kaynaklı yağmurlama yöntemi kullanılarak farklı sulama düzeyleri olușturmușlar. Laterale en yakın (I1) konusuna uygulanan toplam sulama suyu miktarı iki deneme yılında 344-400 mm olduğunu belirtmișlerdir.

Araștırma yıllarında farklı sulama yöntemleri ve konularına ait dane verim değerleri Çizelge 1'de, dane verimine ilișkin LSD gruplandırması Çizelge 2'de verilmiștir. Her iki araștırma yılında da sulama konularının verim üzerine etkileri istatistiksel olarak \% 1 de önemli bulunmuș ancak farklı damla sulama yöntemleri ve sulama konuları interaksiyonu önemsiz çıkmıștır. Kinoa bitkisinden elde edilen dane verimleri ilk yıl 2204.1 kg ha-1 ile 2906.3 kg ha-1; ikinci yıl ise $1855.3 \mathrm{~kg} \mathrm{ha}^{-1}$ ile $2468.2 \mathrm{~kg}$ $\mathrm{ha}^{-1}$ arasında değișmiștir. Her iki araștırma yılında ve her iki damla sulama yönteminde en yüksek verim tam sulama (FI) konusunda, bu sırayı RDI, DI-75, PRD-50, Dl-50 ve en düșük verim ile RF konusu izlemiștir. Kısıntılı sulamaların verimi azalttığı gözlenmiștir. Araștırmanın ilk yılında genel olarak YD konularında elde edilen dane verimleri TD konularından ortalama \%3 oranında daha yüksek olmuștur. Bunun nedeni kök bölgesinde sulamadan sonra doygun bir toprak hacminin olușması sonucu kök ve bitki gelișiminin olumsuz etkilenmesi olabilir. Sezen vd. (2018), Çukurova bölgesinde kinoa (Titicaca çeșidi) bitkisinde yaptıkları çalıșmada en yüksek verim laterale en yakın (11) konuda 4510-4880 kg ha-1, en düșük verim ise laterale en uzak (susuz) konudan (15) 1430-1880 kg ha-1 elde etmișlerdir. Hirich vd. (2014), tam sulama uygulamasında yetiștirilen kinoa bitkisinden 3000 kg ha-1 dane verimi elde

Çizelge 2. Araștırma yıllarında Kinoa bitkisinde verime ilișkin LSD gruplandırması

Table 2. LSD grouping on yield in quinoa plant during research years

\begin{tabular}{ccc}
\hline \multirow{2}{*}{ Sulama Konuları } & \multicolumn{2}{c}{${\text { Dane Verimi, } \mathrm{kg} \mathrm{ha}^{-1}}$} \\
\cline { 2 - 3 } FI & 2016 & 2017 \\
DI-75 & $2906.3 \mathrm{a}$ & $2320.5 \mathrm{bc}$ \\
DI-50 & $2807.8 \mathrm{a}$ & $2074.0 \mathrm{~d}$ \\
PRD-50 & $2481.6 \mathrm{~b}$ & $2206.9 \mathrm{C}$ \\
RDI & $2734.7 \mathrm{ab}$ & $2438.1 \mathrm{ab}$ \\
RF & $2825.6 \mathrm{a}$ & $1855.3 \mathrm{e}$ \\
Istatistiksel Analiz & $2204.1 \mathrm{C}$ & $\mathrm{P}=0.0001 * * \mathrm{LSD}=121.4$
\end{tabular}

$\mathrm{P}<0.01$ (** \%1 düzeyinde önemli) $\mathrm{P}<0.05$ (* \%5 düzeyinde önemli ) $P>0.05$ öd (önemli değil) 
edilirken, \%50 kısıntılı sulama uygulanan kinoa bitkisinden 1700 t ha $^{-1}$ dane verimi elde edildiğini bildirmiștir. Danimarka'da Titicaca kinoa çeșidinde stressiz koșullarda elde edilen dane verimi 3300 kg ha-1 (Razzaghi vd., 2011) iken; Yazar ve İncekaya (2014), Çukurova Bölgesinde aynı kinoa çeșidi kullanılarak yapılan araștırmada verimin stressiz koșullarda 2000 ile 3000 kg ha-1 arasında değiștiğini belirtmișlerdir.

Üreticilerin, önerilen yeni yetiștirme tekniğini benimsemeleri ancak daha fazla ekonomik getiri elde etmeleri durumunda mümkün olabilir. Farklı damla sulama yöntemleri ve sulama konularının ekonomik analizleri Cizelge 3-4'de ayrıntılı olarak verilmiștir. Yatırım, ișletim ve üretim giderlerini kapsayan ekonomik analiz sonuçlarına göre farkı sulama yöntemi ve sulama konularında net gelirler 2016 yılında 4954-8493 \$ ha-1 arasında değișmiștir. En yüksek net gelir YD sulama yönteminde FI konusunda $8493 \$$ ha $^{-1}$ elde edilirken, bu konuyu aynı sulama yönteminde Dl-75 konusu 8183 \$ ha ${ }^{-1}$ izlemiștir (Cizelge 3). 2017 yılında da 32705906 \$ ha-1 arasında değișmiștir. En yüksek net gelir TD sulama yönteminde FI konusunda 5906 \$ ha-1 elde edilirken, bu konuyu YD sulama yöntemi Fl konusu 5713 \$ ha-1 izlemiștir (Cizelge 4). Her iki yılın ortalaması değerlendirildiğinde en yüksek net gelir YD sulama yöntemi FI konusunda 7103\$ ha ${ }^{-1}$ elde edilmiștir. Bu sırayı TD FI, YD DI-75, TD RDI konuları izlemiș ve en düșük net net gelir RF konusunda elde edilmiștir. Sulama yöntemlerine göre kıyasladığımızda YD sulama yöntemlerinde TD sulama yöntemine göre daha yüksek net gelirler elde edilmiștir. Tam sulamalardan sonra DI-75 ve RDI konularında yüksek net gelirler hesaplanmıștır. Her iki sulama yönteminde de PRD-50 ile DI-50 konuları aynı sulama suyu miktarlarını almalarına rağmen her iki konuyu kıyasladığımızda PRD-50 konularında daha yüksek net gelir hesaplanmıștır. Araștırmanın her iki yılında azalan sulama suyu ile net gelirde azalma görülmüștür. Sezen vd. (2018), Çukurova bölgesinde kinoa (Titicaca) bitkisinde yaptıkları çalıșmada ekonomik değerlendirme sonucunda marjinal gelirler 11 (laterale en yakın) sulama düzeyinden $9120 \$ \mathrm{ha}^{-1}$, diğer bir deyișle tam sulama konusundan alınmıștır. Azalan sulama suyu miktarına bağlı olarak marjinal gelir değerleri düșmüștür. Su kıtlığı olması durumunda sulama suyunda yaklașı \%20-25 kısıntı yapılması (I2 konusu) ile kabul edilebilir marjinal verim sağlanabileceğini belirtmișlerdir.

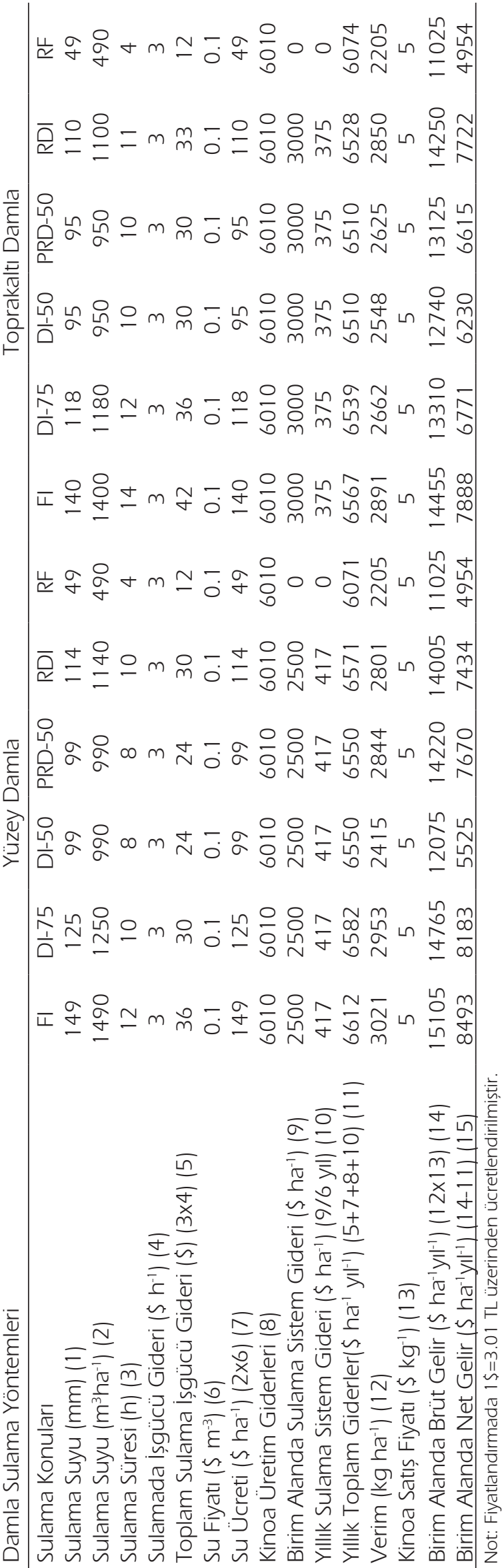




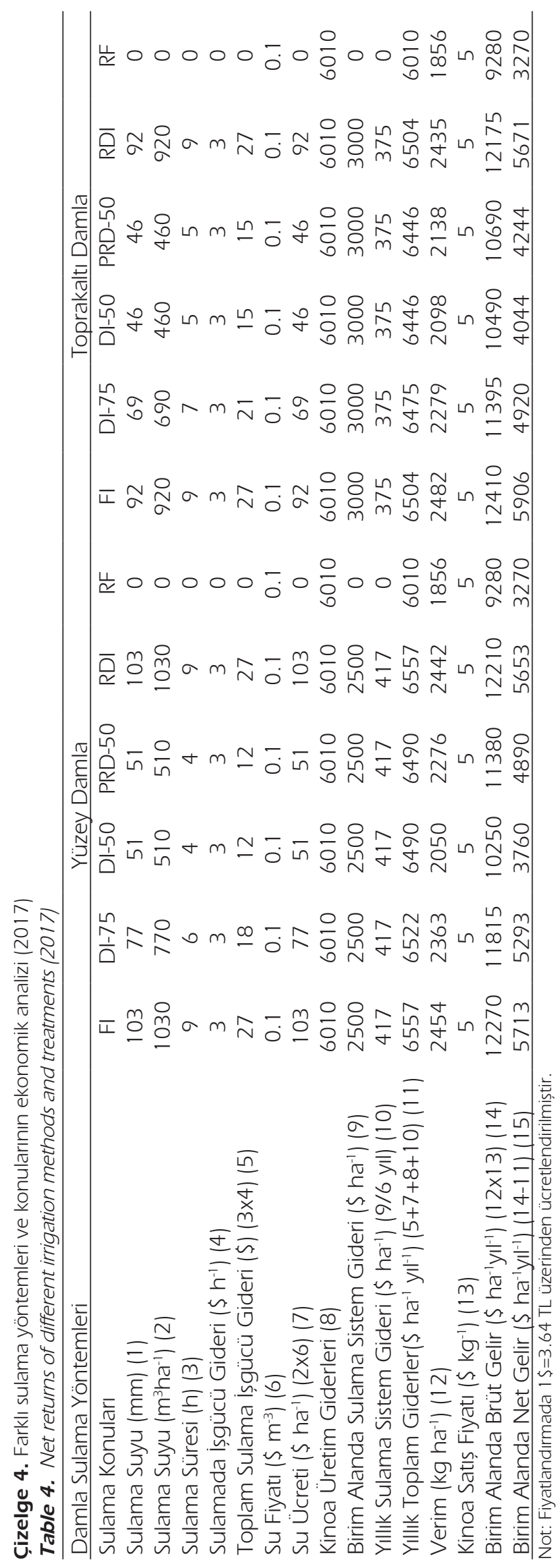

\section{SONUC̣LAR}

Çukurova Bölgesinde kinoa bitkisinde farklı sulama yöntemleri ve sulama konularının verim üzerine etkisi ve ekonomik analizinin yapıldığı iki yıllık çalıșmadan elde edilen sonuçlar ıșığında șu öneriler yapılabilir.

Her iki sulama yönteminde de aynı sulama konularındaki verimler arasında önemli bir fark görülmemiștir. En yüksek verim her iki deneme yılında FI konularında görülmüștür. TD sulama yönteminde YD yöntemine göre daha az buharlașma kaybı olduğundan daha az sulama suyu uygulanmıștır. RDI sulama konusu YD ve TD sulama yöntemleri için sırasıyla \%21 ve 23 oranında su tasarrufu sağlamıștır. Dl-75 konusu her iki sulama yöntemi için de \%17'lik su tasarrufu sağlamıștır. Her iki sulama yöntemi için de daha az sulama suyu uygulaması yapılan RDI sulama konusunun FI konusuna yakın verim alındığından kısıtlı su koșulları için iyi bir alternatif olabilir.

Ekonomik analiz sonucunda marjinal gelirler her iki sulama yöntemi için Fl konularından alınmıștır. Sulama yöntemlerine göre kıyasladığımızda YD sulama yöntemi sulama konularının TD sulama yöntemi sulama konularına göre daha yüksek net gelirler elde edilmiștir. Tam sulamalardan sonra DI-75 ve RDI konularında yüksek net gelirler hesaplanmıștır. Azalan sulama suyu miktarına bağlı olarak marjinal gelir değerleri düșmüștür. Sonuçta YD sulama yönteminin FI sulama konusunun ön plana çıktığı ancak kısıtlı su koșullarında RDI ve DI75 sulama konularının iyi bir alternatif olabileceği önerilmektedir.

\section{TEȘEKKÜR}

Yazarlar adına TUBITAK ERANET-2150951 nolu proje için sağladığı finansal destek için Türk Bilimsel ve Teknik Araștırma Kurumu'na (TÜBITAK) teșekkür ederiz. Ayrıca, bu makalenin "Materyal ve Yöntem" bölümünün bir kısmı, ilgili proje verilerinden üretilen farklı makale veya yayın(lar)'ın yalnız "Materyal ve Yöntem" bölümlerinin bir kısmı ile benzerlik göstermektedir.

\section{KAYNAKLAR}

Aguilar PC, Jacopsen SE (2003). Cultivation of quinoa on the Peruvian Altiplano. Food Reviews Int., 19, 31-41.

Barker R, Dawe D, Inocencio A (2003). Economics of water productivity in managing water for agriculture. In: Kijne JW, Barker R, Molden M (eds). Water productivity in agriculture: limits and opportunities for improvement. CABI Publishing, UK. 332pp. 
Bozkurt Colak Y, Yazar A, Alghory A, Tekin S (2020). Evaluation of crop water stress index and leaf water potential for differentially irrigated quinoa with surface and subsurface drip systems. Irrigation Science. DOI: 10.1007/s00271-02000681-4.

Candemir S, Kızılaslan N, Kızılaslan H, Uysal O, Aydoğan M (2017). Kahramanmaraș ilinde dane mısır ve pamuk üretiminde girdi gereksinimi ve karlııkları açısından karșılaștırmalı analizi. Türk Tarım ve Doğa Bilimleri Dergisi, 4(1), 1-8.

FAO (2017). http://www.fao.org/faostat/en/\#data/OC.

Garcia M, Raes D, Jacobsen SE (2003). Evapotranspiration analysis and irrigation requirements of quinoa (Chenopodium quinoa) in the Bolivian highlands. Agr. Water Manage., 60, 119-134.

Geerts S, Raes D, Garcia M, Condori O, Mamani J, Miranda R, Cusicanqui J, Taboada C, Yucra E, Vacher J (2008). Could deficit ırrigation be a sustainable practice for quinoa (Chenopodium quinoa Willd.) in the Southern Bolivian Altiplano? Agricultural Water Management, 95(8), 909-917.

Hirich A, Jelloul A, Choukr-Allah R, Jacobsen SE (2014). Saline water irrigation of quinoa and chickpea: seedling rate, stomatal conductance and yield responses. Journal of Agronomy and Crop Science 200 (5), 378-389

Jensen CR, Jacobsen SE, Andersen MN, Nunez N, Andersen SD, Rasmussen L, Mogensen VO (2000). Leaf gas exchange and water relation characteristics of field quinoa (Chenopodium quinoa Willd.) during soil drying. European J. Agron., 13, 11-25.

Kır AE, Temel S (2017). Sulu koșullarda farklı kinoa (Chenopodium quinoa Willd.) genotiplerinin tohum verimi ile bazı tarımsal özelliklerinin belirlenmesi. Iğdır Üniversitesi Fen Bilimleri Enstitüsü Dergisi, 7(1), 353-361.

Martinez E, San Martin R, Jorquera C, Veas E, Jara P (2009). Reintroduction of quinoa into arid Chile: cultivation of two lowland races under extremely low irrigation. J. Agron. Crop Sci., 195, 1-10.
Oweis TY, Hachum AY (2003). Improving Water Productivity in the Dry Areas of West Asia and North Africa. In: Water Productivity in Agriculture: Limits and opportunities for improvement (Edited by: Kijne J.W., Barker, R., Molden, D.). CABI Publishing, $328 \mathrm{~s}$.

Razzaghi F, Ahmadi SH, Adolf VI, Jensen CR, Jacobsen SE, Andersen MN (2011) Water relations and transpiration of quinoa (Chenopodium quinoa Willd.) under salinity and soil drying. Journal of Agronomy and Crop Science 197 (5), 348360.

Sezen SM, Tekin S, Yıldız M (2018). Çukurova bölgesinde drenaj suyu ile sulanan kinoa bitkisinde su-verim ilișkileri ve ekonomik değerlendirme. Derim, 35 (2), 173-185.

Kadyampakeni DM, Kazombo-Phiri S, Bancy Mati SB, Isaac R, Fandika IR (2014). Impacts of small-scale water management interventions on crop yield, water use and productivity in two agro-ecologies of Malawi. Agricultural Sciences, 5, 454-465

Vega-Galvez A, Miranda M, Vergara J, Uribe E, Puente L, Martinez EA (2010). Nutrition facts and functional potential of quinoa (Chenopodium quinoa Willd.), an Ancient Andean grain: a review. Journal of the Science Food Agriculture. 90: 2541-2547.

Yazar A, Ince Kaya C (2014) A new crop for salt affected and dry agricultural areas of Turkey: Quinoa (Chenopodium quinoa Wild.). Turkish Journal of Agricultural and Natural Sciences Special Issue: 2, 1440-1446.

Yazar A, İnce Kaya C, Sezen SM, Jacobsen SE (2015) Saline water irrigation of quinoa (Chenopodium quinoa) under Mediterranean conditions. Crop \& Pasture Science 66, 9931002. 